1 Clarkson JA, Fine PEM. The efficiency of measles and pertussis notification in England and Wales In f Epidemiol 1985;14:153-68.

2 Collingham KE, Pollock TM, Roebuck MO. Paralytic polio in England and Wales 1976-77. Lancet 1978;i:976-8.

3 Noah ND. Measles eradication policies. BrMed I 1982;284:997-8.

Department of Health and Social Security. Health Services Management. Measles immunisation. London: Department of Health and Social Security, 1984. (HN (84) 19.)

Noah ND. Epidemiological aspects of viral vaccines. In: Waterson AP, ed. Recent advances in clinical virology. Edinburgh: Churchill Livingstone, 1983:187-204.

\section{Infiltrating lobular carcinoma of the breast}

The nosological entities identified by pathologists should have clinical relevance. For a primary malignant tumour the clinician would ideally like the pathologist to predict the probability and pattern of secondary spread and the chances of response to treatment. Recent reports on the behaviour of infiltrating lobular carcinoma-the second most common carcinoma (at least $8 \%$ of invasive breast carcinomas) after infiltrating duct carcinoma-suggest that progress is being made towards this ideal.

Infiltrating lobular carcinoma is distinguished from infiltrating duct carcinoma histologically by its small cells, diffusely infiltrative pattern, and the formation of characteristic linear arrays or "Indian files" of tumour cells that sometimes form targetoid patterns around non-neoplastic ducts. ' Three variants of this classical pattern have been described and designated solid, alveolar, and mixed, according to the histological picture..$^{1-3} \mathrm{~A}$ further variant, signet ring cell carcinoma of the breast, is characterised by large and frequent intracytoplasmic lumina ${ }^{4}$; this form of infiltrating lobular carcinoma should be distinguished from the rare signet ring type of mucoid carcinoma, which is a form of duct carcinoma. ${ }^{56}$

What does the diagnosis of infiltrating lobular carcinoma tell the clinician? Taken overall, infiltrating lobular carcinoma appears to have the same likelihood of axillary node infiltration and distant metastases and the same survival rates as infiltrating duct carcinoma. ${ }^{78}$ Classical infiltrating lobular carcinoma has a better prognosis and the solid variant a poorer prognosis than infiltrating duct carcinoma." Furthermore, there appear to be differences in the distribution of metastases and in oestrogen receptor status between infiltrating lobular carcinoma and infiltrating duct carcinoma.

The differences in metastatic pattern between the two types of tumour which have been reported may influence clinical presentation and management. ${ }^{7}$ Infiltrating lobular carcinoma tends to produce diffuse or finely nodular infiltration of the peritoneum and retroperitoneum, which is often associated with diffuse infiltration of the stomach wall, ovaries, and uterus. ${ }^{7910}$ (Metastatic infiltrating duct carcinoma spreads to these sites much less frequently, and, when it does, tends to form large nodules, contrasting with the diffuse pattern of infiltrating lobular carcinoma.) Retroperitoneal infiltration may also spread to the walls of the ureters $^{7911}$ and cause a functional block of urinary flow. Hydronephrosis is a common accompaniment of this finding and the patient may rarely present with the sudden onset of loin pain and perinephric extravasation of urine. Usually, however, the hydronephrosis is silent and not associated with an increased incidence of urinary tract infection. ${ }^{11}$

The retroperitoneum may be the site where metastases are first detected in patients who undergo mastectomy and are followed up with serial bone scans. In a recent report of patients who developed metastatic infiltrating lobular carcinoma half showed a gradual increase in retention of isotope within the pelvis of the kidney, indicating progressive hydronephrosis. This was not seen in patients with metastatic infiltrating duct carcinoma who were followed up in the same way."

When infiltrating lobular carcinoma metastasises to the central nervous system it almost always produces symptoms and signs of carcinomatous meningitis. ${ }^{12}$ The cerebrospinal fluid contains malignant cells, protein concentration is raised, and glucose concentration reduced. By contrast, infiltrating duct carcinoma is almost always associated with parenchymal deposits; thus the presentation of metastases in the central nervous system in the two tumour types is quite different.

Widespread infiltration of organs with infiltrating lobular carcinoma cells may lead to the serendipitous diagnosis of carcinoma of the breast. We have made the diagnosis of primary infiltrating lobular carcinoma after seeing characteristic cells in biopsy specimens from the cervix, bladder, endometrium, gall bladder, and stomach. In the latter it may be misdiagnosed as linitis plastica. ${ }^{910}$

Several studies, ${ }^{13-15}$ though not all, ${ }^{16}$ have shown that the proportion of oestrogen receptor positive tumours is higher in infiltrating lobular carcinoma than in infiltrating duct carcinoma. In our own series the proportion of breast carcinomas with detectable oestrogen receptors was $82 \%$ for infiltrating lobular carcinoma (compared with $63 \%$ for infiltrating duct carcinoma), and this is associated with a higher probability of response to endocrine treatment in patients who go on to develop metastatic disease.

The findings outlined above show the distinctive nature of infiltrating lobular carcinoma. This may reflect an origin of these tumours from a different cell type within the breast than infiltrating duct carcinomas or, more probably, from a single cell type that may differentiate along separate pathways into either infiltrating lobular carcinoma or infiltrating duct carcinoma. The distinctive pattern of spread of infiltrating lobular carcinomas may be associated with determinants on the cell surface-as yet not identified-that are not shared by infiltrating duct carcinomas.

ANTHONY HowELL Senior lecturer in medical oncology

MARTIN HARRIS Consultant pathologist

Christie Hospital and

Holt Radium Institute Manchester M20 9BX

1 Martinex VM, Azzopardi JG. Invasive lobular carcinoma of the breast: incidence and variants Histopathologv 1979;3:467-88.

Fechner RE. Histologic variants of infiltrating lobular carcinoma of the breast. Hum Pathol 1975;6:373-8.

Dixon JM, Anderson TJ, Page DL, Lee D, Duffy W. Infiltrating lobular carcinoma of the breast. Histopathology 1982;6:149-61.

Steinbrecher JS, Silverberg SG. Signet ring cell carcinoma of the breast, the mucinous variant of infiltrating lobular carcinoma. Cancer 1976;37:828-40.

5 Gad A, Azzopardi JG. Lobular carcinoma of the breast: a special variant of mucin-secreting carcinoma. J Clin Pathol 1975:28:711-6.

6 Harris M, Vasudev KS, Anfield C, Wells S. Mucin-producing carcinomas of the breast: ultrastructural observations. Histopathologv 1978;2:177-88.

7 Harris $M$, Howell A, Chrissohou M, Swindell R, Hudson M, Sellwood RA. A comparison of the metastatic pattern of infiltrating lobular carcinoma and infiltrating duct carcinoma of the metastatic pattern of infiltrating lobu
breast. Br f Cancer 1984:50:23-30.

breast. Brf Cancer 1984;50:23-30.
Ashikari R. Huvos AG, Urban JA, Robbins GF. Infiltrating lobular carcinoma of the breast. Ashikari R, Huvos AG,
Cancer 1973;31:110-6.

9 Merino MJ, Livolski VA. Signet ring carcinoma of the female breast: a clinicopathologic analysis of 24 cases. Cancer 1981;48:1830-7.

10 Cormier WJ, Gaffey TA, Welch JM, Welch JS, Edmonson JH. Linitis plastica caused by metastatic lobular carcinoma of the breast. Mayo Clin Proc 1980;55:747-53. 
11 Wilkinson MJS, Howell A, Harris M, et al. Retroperitoneal tumour infiltration detected by bone scanning in patients with infiltrating lobular carcinoma of the breast. Br $\mathcal{Y}$ Surg (in press).

12 Smith DB, Howell A, Harris M. Bramwell VHC, Sellwood RA. Carcinomatous meningiti assiciated with infiltrating lobular carcinoma of the breast. European Journal of Surgical Oncology 1985;11:33-60.

13 Antoniiades K, Spector H. Correlation of estrogen receptor levels with histology and cytomorphology in human mammary cancer. Am f C Clin Pathol 1978;71:497-503.

14 Silversward S, Gustafsson J, Gustaffson J, et al. Estrogen receptor concentrations in 269 cases of histologically classified human breast cancer. Cancer 1980;45:2001-5.

15 Rasmussen BB, Rose C, Thorpee SM, Hou-Jensen K, Daehnfeldt JL, Palshof T. Histopathological characteristics and oestrogen receptor content in primary breast carcinoma. Virchowes Arch (Pathol Anat) 1981;390:347-51.

16 Lesser ML, Rosen PP, Senie RT, Duthie K, Menendez-Botet C, Schwartz MK. Estrogen and progesterone receptors in breast carcinoma. Cancer 1981;48:299-309.

\section{Community care: rhetoric and action}

Community care has been said to represent the first big policy change in psychiatry since the early nineteenth century, when the horrors of private madhouses led to the creation of the public asylums. But if planned on the cheap-or not planned at all-community care may be worse than the services it has been replacing for the past 30 years. The Social Services Committee has spoken of the "decanting" of patients from mental hospitals in the past without sufficient services for them. ${ }^{1}$ In addition to those leaving mental hospitals new chronic patients, who would in the past have spent long periods in hospital, have needs that must be supplied in the community. In the short and the longer term more not less money will be needed. ${ }^{12}$

Community care is, then, much more than "deinstitutionalisation"- - which indeed does not in itself abolish institution type practices and attitudes. ${ }^{3}$ It calls for planning at several different levels as much as for resources. A conference held recently at the North London Postgraduate Centre, Haringey, looked at planning for rehabilitation and resettlement in the context of the closure of mental hospitals. Discussions were given a focus by the plans for closing Claybury Hospital completely and Friern Hospital partially and in particular by developments in the Borough of Haringey. These closures, planned for 1993, will be the first to affect inner city areas in Britain. The experience of Hackney, however, is relevant: its psychiatric services stopped depending on a mental hospital (Long Grove, Epsom) in 1974 and it has evolved comprehensive district based facilities. ${ }^{4}$ Camberwell, moreover, is a London borough with a well researched pattern of community services, ${ }^{5}$ though centred on the Maudsley Hospital; and the meeting drew on the experience of Netherne Hospital in Surrey, with its long tradition of rehabilitation ${ }^{6}$ and its present prospect of cutbacks.

We must develop services to fit the patients instead of hammering patients into a shape to fit the services, as one participant put it; and clearly this means establishing or expanding a wide range of facilities with plenty of time to prepare those leaving hospital and to make arrangements for staff. But it also means more underpinning of information and research than might be supposed. Even the questions of numbers are not straightforward. How accurately can planners predict the numbers needing different types of facility five or 10 years hence, given that a different pattern of services may generate genuinely different needs? For example, the large number of people apparently needing inpatient care at present reflects the past reliance on long term hospital beds. Long stay patients are already being $\frac{3}{\infty}$ discharged from Friern and Claybury Hospitals and matched $\stackrel{\varrho}{c}$ groups of "movers" and "stayers" will be compared in a $\widehat{\supset}$ study under the auspices of the North East Thames Regional $\overline{\bar{F}}$ ' Health Authority Mental Health Research Committee. This ग research will help in assessing the value of the community $\$$ services and in future planning. A computerised psychiatric services register (with safeguards to protect confidentiality) is being set up at the Community Psychiatry Research Unit of $\stackrel{\vec{\sim}}{\rightarrow}$ St Bartholomew's Hospital Medical College. This will help믈 coordination between different parts of the service-in $\frac{\bar{\sigma}}{\bar{\omega}}$ particular, people with psychiatric disabilities will be less $\vec{\nabla}$ likely to fall through the net and get lost in the communityand it will provide a database for planning and research. के

More generally, changes of such magnitude in the pattern $\vec{\circ}$ of services call for research on the long term outcome for those concerned. This should include not only the broad $\stackrel{\omega}{\omega}$ outlines but also a more secure base of knowledge of how $\frac{5}{3}$ people with these chronic disabilities actually live in the community-do they eat adequately, for instance; what $\stackrel{6}{6}$ satisfactions do they have in their lives; and what do they or themselves want? The Community Psychiatry Research Unit of has many projects in hand, but salaries are funded only on a $\vec{\omega}$ yearly basis, and long term research is not guaranteed. This is not good enough. Vast numbers of long term patients have $\vec{\rho}$ been discharged in the past three decades and it is truly $\overrightarrow{\vec{\sigma}}$ remarkable that we do not know what proportions have $\Omega$ settled successfully in the community with family or other support, have struggled on in a lonely abyss, have lived a life of destitution, and have returned to hospital.

Running through the many recommendations thrown up by the meeting were a few common themes: firstly, provision $\vec{\oplus}$ of comprehensive local services (including the long term beds $\sigma$ and day hospital places needed for the most seriously disabled) with the flexibility to meet the needs of individuals; secondly, more effective planning, with coordination among health, social, and other services and voluntary agencies and $\frac{\%}{\varnothing}$

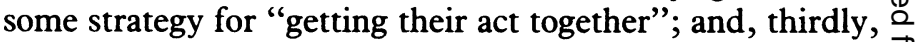
monitoring and long term research, aided by computerised $\overrightarrow{\overrightarrow{0}}$ registers. But government itself has to take on board the increased demand for resources if community based services, with if necessary lifelong commitment to individuals, are to work; and it cannot be expected to do this without more precise information on needs and on outcome than is available.

The value of such meetings lies not so much in the novelty of the proposals as in the detailed discussion of practical issues between miscellaneous workers and administrators $ᄋ$ who are treading these thorny paths and those who have already travelled them and found answers-perhaps the hard $\rightarrow$ way. As the select committee put it, "the rhetoric of community care has to be matched by action."

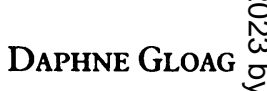

Staff Editor

$B M \mathcal{F}$ 1 Social Services Committee. Second Report. Community care with special reference to adult mentally ill 2 Anonymous. Community care [Editorial]. Br Med f 1985;290:806.

3 Bennett D, Morris I. Deinstitutionalisation in the United Kingdom. International foumal of Mental Health 1983;ii:5-23.

4 Reed J. The elements of an ideal service: the clinical view. In: Reed J, Lomas G, eds. Psychiatric services in the community. Developments and innovations. London: Croom Helm, 1984:77-85. Wing JK, ed. Long-term community care: experience in a London borough. Cambridge: Cambridge University Press, 1982. (Psychological Medicine monogr, suppl 2.)

6 Ekdawi MY. Rehabilitation practice at Netherne Hospital. In: Wing JK, Morris B. Handbook of psychiatric rehabilitation practice. Oxford: Oxford University Press, 1981:172-3. 